\title{
ANTIBACTERIAL EFFICACY OF Anopheles gambiae (MOSQUITOES) EXTRACTS ON SOME BACTERIA CAUSING THROAT INFECTIONS
}

Lateef Adesegun Kasim*1 and Muftau Kolawole Oladunmoye ${ }^{2}$

Address (es): Kasim Lateef Adesegun,

${ }^{1}$ Department of Microbiology, Federal University of Technology Akure, Nigeria.

${ }^{2}$ Department of Microbiology, Federal University of Technology Akure, Nigeria.

*Corresponding author: Checksyr@gmail.com

https://doi.org/10.36547/be.383

\section{ABSTRACT}

Introduction: Respiratory tract infection refers to any infectious disease involving the respiratory tract. In low-income and middle-income countries, respiratory tract infection is considered as one of the major public health problems. It can lead to severe mortality and morbidity in children as well as adults. Over the years there has been a development of resistance to antibiotics used for the treatment of throat infections which has led to the search for alternative therapy. Insects can be potentially useful as an alternative therapy because of the diverse bioactive compounds they possess.

Objective: This research investigated the antibacterial activity of the extract of Anopheles gambiae against bacterial isolates associated with throat infection.

Methods: The insects were bred in microbiology laboratory and identified in the Department of Biology, Federal University of Technology, Akure. The mosquitoes were collect and immobilized in the freezer at $-4^{\circ} \mathrm{C}$. The extracts were prepared by mecrating the mosquitoes into $30 \%$ Dimethlsulfoxide (DMSO) for its homogenization Extracts were then tested against bacterial isolates in-vitro using agar well diffusion method. Results: Extracts were tested against bacterial isolates using agar well diffusion method which showed activity against $S$. pyogenes $\left(22.00 \pm 0.58^{\mathrm{b}} \mathrm{mm}\right), S$. aureus $(19.67 \pm 1.20 \mathrm{~mm})$ and $K$. pneumoniae $(24 \pm 1.15 \mathrm{~mm})$, while it showed no activity against E. coli and S. pneumoniae. Conclusion: A. gambiae extract may be considered as an alternative in medicine to combat the issue of increasing multidrug resistance to conventional antibiotics, the side effects of these antibiotics and high cost of synthetic drugs production. The most prevalent compound was n-hexadecenoic with retention time of 20.997 , which was reported to exhibit antioxidant and antimicrobial activity.

Keywords: Anopheles gambiae, Throat Infections, in-vitro, Gas-Chromatography Mass Spectometry

\section{INTRODUCTION}

Increase in the resistance of micro-organisms to antibiotics encouraged scientists to search for new antimicrobial substances from various sources including medicinal plants, microbrobes and e.t.c. Insects have been extensively used all over the past for medical dealing on nearly every continent. Scanty or little medical entomological studies has been conducted since the revolutionary arrival of antibiotics (Rajkhowa et al., 2016). Arthropods represent a rich and largely unexplored source of new medicinal compounds (Dossey 2010). A large number of studies have been carried out by the scientist on the composition of chemical which are present in insect body, used to treat various disease like venom present in honeybee, wasps; cantharidin produced by blister beetle for treating cancer etc. In January 2004, the U.S. Food and Drug Administration (FDA) granted permission to produce and market maggots for use in humans or animals as a prescription-only medical device for the following indications: "For debriding nonhealing necrotic skin and soft tissue wounds, including pressure ulcers, venous stasis ulcers, neuropathic foot ulcers, and non-healing traumatic or post-surgical wounds (Heitkamp et al., 2013). Insects can produce a variety of antimicrobial peptides which are commonly called Insect AMPs (Hui-Yu et al., 2014). AMPs are naturally occurring peptides produced as a first line of defense against pathogenic infections by virtually all living species, from bacteria to mammals (Zhang and Gallo, 2016). AMPs play an essential role in those organisms that lack an adaptive immune system and base their defense only on the innate immune response (Brady et al., 2019). They provide the first line of defense against a variety of pathogens. AMPs display synergistic effects with conventional antibiotics, and thus present the potential for combined therapies. These AMPs makes Insects extremely resistant to bacterial infections (Qinghua et al., 2018). Anopheles defensin shows antibacterial and antifungal activities at physiological concentrations (Vizioli, 2001) and its expression is strongly up-regulated on infection by bacteria or Plasmodium (Richman, 1997). The Anopheles defensin and cecropin are expressed in the midgut, thorax, and abdominal tissues of naive mosquitoes. These peptides are preferentially expressed in the anterior part of the midgut (Richman, 1997). Anopheles cecropin A and its mRNA are inducibly expressed in cell lines and mosquitoes and both mediated and non-mediated isoforms of this ceropin are active against a broad spectrum of microorganisms (Richman, 1997).

\section{MATERIALS AND METHODS}

\section{Collection of Anopheles gambiae}

Mosquitoes were allowed to lay eggs in water in which the eggs were identified by a biologist. The eggs were then collected in separate container containing some amount of yeast which was fed on by the larva, the container were covered with a net and the adult mosquitoes were collected for processing.

\section{Preparation and purification of Anopheles gambiae extract}

The Mosquitoes were killed by placing them in a freezer for about 10 to 20 minutes until they became immobilized. The mosquitoes were sterilized in $70 \%$ ethanol to remove the microfloras present on their surfaces. They were processed by macerating them separately in a clean dry mortar and pestle. 5grams of was dissolved into $10 \mathrm{ml}$ of $20 \%$ Dimethylsulfoxide (DMSO) and kept in the refrigerator for 24 hours according to the method of Evans and Vidhu, (2015). After 24 hours, they were then centrifuged and purified by passing them through Millipore filter paper and used for in-vitro antibacterial evaluation.

\section{Source of bacteria strains}

Stock cultures of bacteria isolates from throat samples (Escherichia coli, Staphylococcus aureus, Klebsiella pneumoniae, Streptococcus pyogenes and Streptococcus pneumoniae)

\section{Standardization of bacterial inoculum}

A loop full of test bacterial isolates were inoculated on nutrient broth and incubated for 24 hours. $0.2 \mathrm{ml}$ from the 24 hours' broth culture of the bacteria was dispensed into $20 \mathrm{ml}$ sterile nutrient broth and incubated for 3 to 5 hours to standardize the culture to $0.5 \mathrm{McFarland}$ standards $\left(10^{6} \mathrm{CFU} / \mathrm{ml}\right)$ before use according to method described by Clinical Laboratory Standards Institute (CLSI) (2014).

\section{Antibacterial evaluation of Anopheles gambiae extracts in-vitro}

The antibacterial screening was carried out using agar well diffusion method as described by Billah et al. (2015). Sterile cotton wool swabs were used to pick the inocula for the streaking of the entire surfaces of Mueller-Hinton agar (MHA) plates rotating in 3 directions at approximately $60^{\circ}$ for evenly distribution of 
inocula of the tests bacteria on the MHA plates. Then $6 \mathrm{~mm}$ diameter wells were bored in three places on the inoculated MHA plates by the use of a sterile cork borer. Using a micropipette with sterile tips, $100 \mu \mathrm{l}$ of extract stock solutions $(500 \mathrm{mg} / \mathrm{ml})$ was dispensed into one of the wells, chloramphenicol solution was dispensed into the second well to serve as the positive control and 30\% DMSO in the third well in the MHA plate. The set-up was incubated aerobically at $37^{\circ} \mathrm{C}$ for $24 \mathrm{hrs}$. The inhibition zone diameters were measured using meter rule after 24 hours incubation and recorded. The whole experiment was repeated for 2 more consecutive times and the mean diameters of zones of inhibition calculated for each bacteria.

Determination of minimum inhibitory concentration (MIC) and minimum bactericidal concentration (MBC) of Anopheles gambiae extracts against clinical bacterial isolates from throat swab samples

The minimum inhibitory concentration of the extracts of Anopheles gambiae was determined using the method adopted by Bosso and Innalegwu (2018). The MIC was obtained using the double fold dilution. One millilitre of the extracts reconstituted with 30\% dimethyl sulphoxide (DMSO) at a concentration of 100 $\mathrm{mg} / \mathrm{ml}$ was diluted serially to give different concentrations of $50 \mathrm{mg} / \mathrm{ml}, 25 \mathrm{mg} / \mathrm{ml}$, $12.5 \mathrm{mg} / \mathrm{ml}, 6.25 \mathrm{mg} / \mathrm{ml}$ and $3.125 \mathrm{mg} / \mathrm{ml}$ in test tubes. The honey sample was diluted with $30 \%$ DMSO to produce concentrations of $50 \%, 25 \%, 12.5 \%$ and $3.125 \%$ in different test tubes. One millilitre of 18 -hour culture of the standardized bacterial isolates were added to each of the test tubes and mixed thoroughly. The tubes were then incubated at $37{ }^{\circ} \mathrm{C}$ for about 18 hours. Another tube containing $30 \%$ DMSO with no extract/honey was used as negative control while another tube containing ciprofloxacin was used as the positive control. The lowest concentration of the extracts/honey that shows no visible turbidity of growth was recorded as the MIC. The MBC of the extracts from Anopheles gambiae were determined according to the method adopted by Bosso and Innalegwu (2018). The test tubes from the MIC test above that is without visible growth were aseptically inoculated on different sterile MHA plates and incubated for 24 hours at $37^{\circ} \mathrm{C}$. The MBC was taken as the lowest concentration of extracts/honey that produced $\mathrm{w}$ no visible growth of the bacterial isolates on the plate.

\section{Statistical Analysis}

Statistical analysis was carried out using Statistical Package for Social Sciences (SPSS) version 20. The analysis of variance test was used to determine the statistical significance in the zones of inhibition of the extracts. $P<0.05$ was considered significant.

\section{RESULTS}

\section{Antibacterial activity of crude extracts from A. gambiae}

At the concentration of $500 \mathrm{mg} / \mathrm{ml}$, the extract showed maximum zone of inhibition against $K$. pneumoniae $\left(24 \pm 1.15^{\mathrm{b}} \mathrm{mm}\right)$, followed by isolated $S$. pyogenes $(22.00$ $\left.\pm 0.58^{\mathrm{b}} \mathrm{mm}\right)$ and least effect against isolated $S$. aureus $(19.67 \pm 1.20 \mathrm{~mm})$. No effect was observed on other test organisms. Ciprofloxacin (positive control) showed a maximum activity against $S$. aureus $(41.58 \pm 0.58 \mathrm{~mm})$ and least effect against isolated E. coli $(39.67 \pm 0.33 \mathrm{~mm}$ ). DMSO (negative control) had no effect on all test isolates as shown in figure 1.

Minimum Inhibitory Concentration and Minimum Bactericidal Concentration of A. gambiae whole insect extract

The minimum inhibitory concentration (MIC) and the Minimum Bactericidal concentration of the extract of A. gambiae whole insect against the multiple antibiotic resistant isolates is revealed in Table 1 the MIC on the bacterial isolates ranged from $12.5 \mathrm{mg} / \mathrm{ml}-100 \mathrm{mg} / \mathrm{ml}$. The minimum bactericidal concentration $(\mathrm{MBC})$ on the bacterial isolates ranged from $50 \mathrm{mg} / \mathrm{ml}-100 \mathrm{mg} / \mathrm{ml}$.

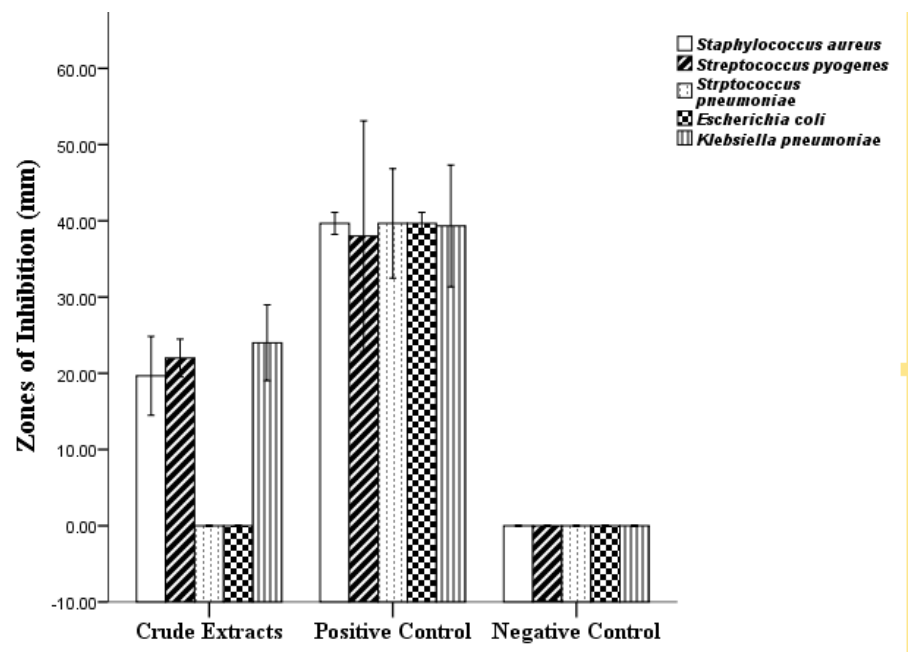

Figure 1 Antibacterial effect of Anopheles gambiae $(500 \mathrm{mg} / \mathrm{ml})$ on Gramnegative and Gram-positive Bacterial isolates from throat samples. Key: Positive control $=$ ciprofloxacin $(0.1 \mathrm{mg} / \mathrm{ml})$, Negative control $=$ DMSO .

Table 1 Minimum Inhibitory Concentration and Minimum Bactericidal Concentration of A. gambiae Whole Insect Extract

\begin{tabular}{lcc}
\hline Bacterial Isolates & MIC $(\mathrm{mg} / \mathrm{ml})$ & $\mathrm{MBC}(\mathrm{mg} / \mathrm{ml})$ \\
\hline Staphylococcus aureus & 50 & 100 \\
StreptococcuS. pyogenes & 12.5 & 50 \\
Klebsiella pneumoniae & 25 & 100 \\
\hline
\end{tabular}

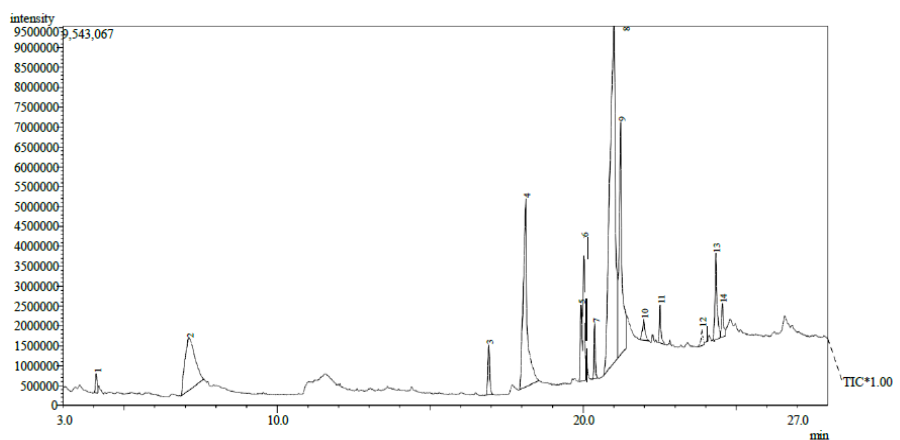

Figure 2 GC-MS Chromatographic Spectra of Whole Insect Extract of Anopheles gambiae

\section{DISCUSSION}

The A. gambiae whole insect extract showed varying antibacterial effects on test bacterial isolates which is in line with Vizioli et al., (2014), who showed varying antibacterial action of A. gambiae defensin peptide against gram positive and gram negative bacteria. The extract showed substantial inhibitory effect on $S$. aureus, $S$. pyogenes and $K$. pneumoniae but it showed no effect on E.coli and S. pneumoniae in this study. Similar result was reported by Vizioli et al. (2001) that reported greater inhibitory activity in A. gambiae defensin peptide on Some gram-positive and gram negative bacterial with the exepction of some strains of E.coli (Escherichia coli 1106 ). The result in this study shows that the A. gambiae insect extract may contain substances that could inhibit the growth of some bacterial isolates causing throat infections. The observed antibacterial effects of A. gambiae extract on the test isolates is believed to be due to the presence of some insect Antimicrobial peptides such as defensins, Gambicin, cecropins and lebocins which have been shown to possess antibacterial properties (Zhao and Lu 2014). The MIC and $\mathrm{MBC}$ techniques are used to evaluate the efficacies of antimicrobial agents and in this study. According to Patel and Patel (2014), if an extract displayed an MIC value $\leq 12.5 \mathrm{mg} / \mathrm{ml}$, the antibacterial activity is considered as excellent. If the MIC value was 25,50 and $100 \mathrm{mg} / \mathrm{ml}$, the antibacterial activity is considered good, moderate and weak respectively. Similarly, if the MIC value is over $100 \mathrm{mg} / \mathrm{ml}$ it is considered as inactive. The extract of A. gambiae whole insect showed an excellent antibacterial activity against multidrug resistant $S$. pyogenes with MIC 
$(12.5 \mathrm{mg} / \mathrm{ml})$. This corroborates with the works of Vizioli et al. (2001) and that at concentrations $(0.4 \mathrm{mg} / \mathrm{ml})$ the extract possesses antibacterial properties. The MBC values were higher than the MIC values in this work. This agrees with Bosso and Innalegwu (2018). This suggests that the extracts were bacteriostatic at lower concentration and bactericidal at higher concentrations (Seanago and Ndip, 2012). The GC-MS analysis of extract of A. gambiae whole insect had 14 peaks and 14 compounds were identified. The most prevalent compound was n-hexadecenoic with retention time of 20.997, which was reported to exhibit antioxidant and antimicrobial activity. The presence of these bioactive compounds may have contributed to antibacterial effects exhibited by extract of $A$. gambiae whole insect therefore, useful in production of potent drugs.

Table 2 The Bioactive Compounds Present in the Extracts from A. gambiae

\begin{tabular}{|c|c|c|c|c|c|}
\hline PEAK & RETENTION TIME & AREA \% & BIOACTIVE COMPOUNDS & EMPIRICAL FORMULA & MOLECULAR WEIGHT (g/mol) \\
\hline 1 & 4.08 & 0.78 & n-Nonylalcohol & $\mathrm{C}_{9} \mathrm{H}_{20} \mathrm{O}$ & 144 \\
\hline 2 & 7.12 & 10.76 & Proline & $\mathrm{C}_{10} \mathrm{H}_{19} \mathrm{NO}_{2}$ & 185 \\
\hline 3 & 16.91 & 2.05 & Pentadecanoic acid & $\mathrm{C}_{17} \mathrm{H}_{34} \mathrm{O}_{2}$ & 270 \\
\hline 4 & 18.12 & 15.82 & n-Hexadecanoic acid & $\mathrm{C}_{16} \mathrm{H}_{32} \mathrm{O}_{2}$ & 256 \\
\hline 5 & 19.93 & 2.41 & 9,12-Ocataecadienoic acid & $\mathrm{C}_{19} \mathrm{H}_{36} \mathrm{O}_{2}$ & 294 \\
\hline 6 & 20.02 & 4.50 & 11-Octadecenoic acid & $\mathrm{C}_{19} \mathrm{H}_{36} \mathrm{O}_{2}$ & 296 \\
\hline 7 & 20.38 & 1.49 & Methyl isoheptadecanoate & $\mathrm{C}_{18} \mathrm{H}_{36} \mathrm{O}_{2}$ & 284 \\
\hline 8 & 20.99 & 39.64 & Z-H-hexadecenoic acid & $\mathrm{C}_{16} \mathrm{H}_{30} \mathrm{O}_{2}$ & 254 \\
\hline 9 & 21.23 & 14.13 & Octadecanoic acid & $\mathrm{C}_{22} \mathrm{H}_{44} \mathrm{O}_{4}$ & 372 \\
\hline 10 & 21.98 & 1.15 & 9-Octadecenal & $\mathrm{C}_{18} \mathrm{H}_{34} \mathrm{O}$ & 266 \\
\hline 11 & 22.51 & 1.18 & 2,3-hydroxylpropylester & $\mathrm{C}_{19} \mathrm{H}_{38} \mathrm{O}_{4}$ & 330 \\
\hline 12 & 23.88 & 0.65 & E-9-tetradecanal & $\mathrm{C}_{14} \mathrm{H}_{26} \mathrm{O}$ & 210 \\
\hline 13 & 24.33 & 3.98 & E-13-Docosenoic acid & $\mathrm{C}_{22} \mathrm{H}_{42} \mathrm{O}_{2}$ & 338 \\
\hline 14 & 24.55 & 1.45 & Decylfluoride & $\mathrm{C}_{10} \mathrm{H}_{21} \mathrm{~F}$ & 160 \\
\hline
\end{tabular}

\section{CONCLUSION}

The extract of A. gambiae showed better inhibitory effect against some multidrug resistant isolates causing throat infections. Thus, A. gambiae extract may be considered as an alternative to therapy in medicine to combat the increase in multidrug resistant bacteria involve in throat infections and also to minimize the misuse of antibiotics and the huge cost of synthetic drug production

\section{REFERENCES}

BOSSO, S. T., DANIEL, A. I. 2018. Phytochemical and Antibacterial Activity of Methanol Extract of Garcinia kola against Selected Bacteria Isolate. American Journal of Food, Nutrition and Health, 3(1), 26-30. https://www.researchgate.net/publication/323152774

BRADY, D., GRAPPUTO, A., ROMOLI, O., SANDRELLI, F. 2019. Insect Cecropins, Antimicrobial Peptides with Potential Therapeutic Applications. International Journal of Molecular Sciences, 20(23), 5862. https://doi.org/10.3390/ijms20235862।

CLINICAL LABORATORY STANDARDS INSTITUTE. 2014. Performance Standards for Antimicrobial Susceptibility Testing. Twenty-Fourth Informational Supplement. CLSI document M100-S24 Wayne,34(1), 50-98.

DOSSEY, A.T. 2010. Insects and their chemical weaponry: new potential for drug discovery. Natural Product Report journal, 27(1), 1737-1757. https://doi.org/10.1039/C005319H

HEITKAMP, A., PECK, R., GEORGE, W., BENJAMIN, C. 2013. "Maggot Debridement Therapy in Modern Army Medicine: Perceptions and Prevalence". Military Medicine, 177(11), 1411-1416. http://doi:10.7205/milmed-d-12-00200 HUI-YU, Y., MUNMUN, C., YA-DONG, H., XIAO-QIANG,Y. 2014. Insect antimicrobial peptides and their applications. Applied Microbiolology and Biotechnology, 98, 5807-5822. http://doi:10.1007/s00253-014-5792-6

PATEL, N.B., PATEL, K.C. 2014. Antibacterial Activity of Euphorbia hirta L. Ethanomedicinal Plant against Gram Positive UTI Pathogens. The World Journal of Engineering and Applied Sciences, 1(1), 1-5.

QINGHUA, WU., JI'RÍ, P., KAMIL, K. 2018. Insect Antimicrobial Peptides. $a$ Mini Review., Department of Radiology and Toxicology, Faculty of Health and Social Studies, University of South Bohemia, 37005 Ceske Budejovice, Czech Republic Toxins, 10,461. http://doi:10.3390/toxins10110461

RAJKHOWA, D., ROKOZENO, M., DEKA., M. 2016. Insect-based Medicines: A Review of Present Status and Prospects of Entomo-Therapeutic Resources for Human Ailment. International Journal of Agriculture. Environment and Biotechnology, 9(6), 1069-1079. http://doi:10.5958?2230-732X.2016.00135.2
RICHMAN, A., DIMOPOULOS, G., SEELEY, D., KAFATOS, F. C. 1997 EMBO Journal, 16(1), 234-237

SEANEGO, C. T., NDIP, R. N. (2012). Identification and Antibacterial Evaluation of Bioactive Compounds from Garcinia kola (Heckel) Seeds. Molecules, 17, 65696584. http://doi: 10.3390/molecules17066569

VIZIOLI, J., BULET, P., HOFFMANN, J. A., KAFATOS, F. C., MULLER, H.M., DIMOPOULOS, G. 2001. Gambicin: A novel immune responsive antimicrobial peptide from the malaria vector Anopheles gambiae. Proceedings of the National Academy of Sciences, 98(22), $12630-12635$. https://doi.org/10.1073/pnas.221466798

ZHAO, L., LU, W. 2014. Defensins in innate immunity. Curr Opin Hematol, 21, 37-42. http://doi:10.1097/MOH.000000000000005 